Article

\title{
Reinscribing the Lived Body: A Qualitative Study of Extraordinary Religious Healing Experiences in Norwegian Contexts
}

\author{
Anne Austad ${ }^{1, *}$, Marianne Rodriguez Nygaard ${ }^{1}$ and Tormod Kleiven ${ }^{2}(\mathbb{D}$ \\ 1 Faculty of Theology, Diaconia and Leadership Studies, VID Specialized University, 0319 Oslo, Norway; \\ marianne.rodriguez.nygaard@vid.no \\ 2 Centre of Diaconia and Professional Practice, VID Specialized University, 0319 Oslo, Norway; \\ tormod.kleiven@vid.no \\ * Correspondence: anne.austad@vid.no; Tel.: +47-2245-1910
}

Received: 2 September 2020; Accepted: 22 October 2020; Published: 30 October 2020

\begin{abstract}
Poor health often motivates people to engage in religious and spiritual approaches to healing. However, there is limited research on such experiences from a northern European perspective. This article investigates healing experiences related to Christian faith and practices in Norway by thematic analysis of 25 semi-structured interviews with individuals who have experienced healing of different ailments. In so doing, healing events across diverse contexts are characterised, and the results show that such experiences not only feature practices in which other people are present in prayer, preaching, and the laying on of hands, but also spontaneous extraordinary encounters with a divine being through visions and voices. The healing events are further described as experiences of transformational, powerful touch. In light of the lived body theory, these transformational experiences can be understood as re-inscriptions of health that are manifested in the intertwined bio-psycho-social-spiritual aspects of the body.
\end{abstract}

Keywords: religious healing; extraordinary experiences; lived body; psychology of religion

\section{Introduction}

Previous research has shown that poor health and suffering often motivate people to engage in religious and spiritual healing practices (Ammerman 2013, pp. 250-51; McGuire 2008, p. 120). It has also been found that religious and spiritual encounter experiences like visions and voices have a transformative function (Geels 2014), which, in some cases, has been described as healing (Braud 2012; Nygaard et al. 2017).

Religious and spiritual healing experiences are diverse in terms of the character of the initial suffering, the type of experience, the religious symbols and practices involved, and the perceived outcome. It is therefore questioned whether such experiences should be referred to as many related experiences and practices, rather than as one phenomenon (Pattison 2007, p. 126). This diversity is also reflected in the research field, in which empirical studies are often limited to particular aspects of healing experiences. Such research includes, for instance, case studies of spontaneous remission of specific diseases like cancer (Brown 2012b), studies of distinct practices like healing prayer services (Brown 2012a; Hovi 2015; Hovi and Westerink 2013; Kleiven et al. 2019) or personal, distant prayers 
for health issues (Jors et al. 2015), and studies of specific outcomes like healing without any remaining biomedical illness (Hvidt 2002a, 2002b). ${ }^{1}$

Contrary to such specific investigations, the present article is based on a qualitative study that aimed to explore religious healing experiences across diverse cases. Taking this diversity into consideration, the study approached healing experiences according to what people deem to be healing in order to not overlook possibly important aspects (Henriksen 2016, p. 136; Pattison 2007)-yet within our conceptual working definition of religious healing experiences. That is, religious healing experiences refer to experiences that interfere with and change the conditions that have degraded a human's quality of life in the form of physical, mental, spiritual, and/or relational derangement. It further denotes experiences of health improvement, restoration, or recovery that are not (yet) easily explained by conventional medical models or treatment (Henriksen 2016, p. 136; Krippner and Achterberg 2000). Experiences of religious healing include individuals' reports of their sensations, feelings, thoughts, and imagery before, during, or after a healing event (Krippner and Achterberg 2000, p. 359), in which healing events are specific experiences of shorter duration that are often described as a turning point in people's lives (Nygaard et al. 2017). Finally, the religious component of the working definition of healing experiences means involvement in religious and/or spiritual ${ }^{2}$ interpretations and/or practices (Watts 2011, p. 1).

This article is part of a larger research project investigating religious healing experiences, healing practices, and healing education related to what is understood by the participants as resources from Christian faith and practice in Norwegian contexts. ${ }^{3}$ The sub-study presented in the present article aims to explore characteristics of healing experiences by people living in Norway who report diverse initial ailments, who have experienced distinct healing event(s) by using resources from different Christian practices, and for whom the process and/or outcome is described as healing. The research question is: What characterises healing experiences related to Christian faith and practices in Norway?

\subsection{Extraordinary Religious Healing Experiences and Encounter Experiences}

Religious healing experiences are regarded as one of several extraordinary experiences ${ }^{4}$ (Cardeña et al. 2000, pp. 353-96). White and Brown (2000) brought together large sets of experiences that were previously considered in relative isolation from one another. They categorised 200 types of what they call 'exceptional human experiences' and classified them into nine classes (White and Brown 2000). Among the nine classes are healing experiences, mystical/unitive experiences, and encounter experiences.

1 The Catholic Church, in particular, has elaborated criteria for recognising religious healings as miracles (Hvidt 2002a): (1) The patient must have suffered from a verified physical illness. (2) The healing occurred suddenly. (3) The healing must be complete without any remaining illness (e.g., in the case of cancer, all—not only some-tumours must have disappeared). (4) The healing must be lasting, without relapse.

2 The relationship between religion and spirituality is widely discussed in the psychology of religion (Belzen 2010, pp. 85-88; Hood 2012; Zinnbauer and Pargament 2005). We propose that the conceptual relationship is illustrated by partly overlapping circles of which secular orientations also are a part (La Cour and Hvidt 2010). The use of overlapping circles allows for combinations of religiosity, spirituality, and secularity, as well as for identifying with only one of the concepts. However, as the scope of the present study was on the faith and practices of Christianity, which most often is identified as an institutionalised religion, we use the term 'religious' as a heading in the interest of simplicity.

3 We have previously published three articles in the project; one article based on observation of healing practices and interviews with leaders of such practices (Kleiven et al. 2019), one pilot study on healing experiences (Nygaard et al. 2017) and one article on healig experiences and attachment theory (Nygaard et al. 2020). This is the first article to analyse the extensive material of 25 interviews.

4 Extraordinary experiences are also termed 'anomalous experiences' (Cardeña et al. 2000), non-ordinary experiences (Taves 2020), and paranormal experiences (Henriksen and Pabst 2013). They are ' ... an unusual experience that cannot be explained in terms of conventionally recognized physical, biological, psychological, or sociological processes' (Braud 2012, p. 110). Extraordinary experiences are included in religious narratives, and as such, they might be familiar to religious communities and sometimes also expected to happen. In certain religious milieus, they are not uncommon either, but still (at least in a Norwegian context), they are not everyday experiences, not even in the lives of religious people (Henriksen and Pabst 2013, p. 28). 
A few case studies indicate, however, that healing experiences may also include what this taxonomy classifies as encounter experiences, like visions and voices (Braud 2012). Important to our study of healing is that extraordinary encounter experiences and mystical experiences have been found to be life changing (Geels 2014; Geels and Belzen 2003; Wulff 2000). The healing aspect of this transformation has not yet been extensively explored (Nygaard et al. 2017).

Within the discipline of psychology of religion, the empirical research on extraordinary religious experiences has often emphasised perceived encounters related to a higher reality. In a Nordic context, and with a focus on the Christian faith and practice, those studies have reported encounters with perceived divine beings, such as angels, the Christian God, and/or Jesus (Geels and Belzen 2003; Geels 2001; Geels and Wikström 2006, pp. 215-235; Nygaard et al. 2017; Lundmark 2010, 2017; Henriksen and Pabst 2013, pp. 80-104). Such encounters have been characterised as perceived sensory experiences and described in terms of the five senses (Geels 2014). They have frequently been reported to be visions (Geels 2001, 2014; Geels and Belzen 2003; Lundmark 2010, 2017; Nygaard et al. 2017), auditory experiences of hearing voices (Dein and Littlewood 2007; Geels 2014; Nygaard et al. 2017), and tactile sensations and feelings of warmth (Henriksen and Pabst 2013, pp. 84-104; Nygaard et al. 2017). Mikal Lundmark (2020) developed a typology providing nuances to the perceptual aspects of extraordinary religious experiences by categorising them as (1) sensory experiences, in which external perceptions are reported; (2) imaginative experiences, which are not perceived through the senses but instead as internal bodily perceptions, e.g., dreams or inner images/visions; and (3) mystical experiences of unity, which are often reported without external sensory experiences.

Extraordinary encounter experiences have often been perceived as spontaneous (Geels 2001; Henriksen and Pabst 2013, p. 11; Lundmark 2016; Nygaard et al. 2017). As such, they are apparently different from experiences that occur when people intentionally seek and take part in distinct healing practices, such as the laying on of hands (Henriksen 2018), pilgrimages (e.g., the pilgrimage to Lourdes), penitential prayer, and participation in the veneration of saints, relics, and icons (Porterfield 2005, p. 9). Yet, recent research has focused more on the perceiver's active search for new experiences (Rambo and Farhadian 2014) and the impact of the religious/spiritual milieu in learning to hear voices and receive visions from God (Luhrmann 2012; Russo-Netzer 2017). Gutierrez et al. (2018) studied reported life-changing religious or spiritual experiences among adherents of six world religious traditions as well as atheists and agnostics from the US $(\mathrm{N}=970)$. They suggested that an individual's religious culture is strongly related to his or her likelihood of having a life-changing religious or spiritual experience.

Related to the debate on the role of the mental orientation of the healee and his or her environment are investigations of extraordinary healing experiences in light of the placebo effect. Such studies point to the possibility of healing as a 'natural phenomenon' originating in the capacities for self-healing in the human organism (Kaptchuk 2002), although it is not necessarily seen as the only working cause (Porterfield 2005, pp. 13-18).

There are different research areas within the discipline of psychology of religion that touch on extraordinary healing; for instance, conversion studies (Kirkpatrick 2005, pp. 128-36; Rambo and Farhadian 2014), faith and health studies (Koenig et al. 2012; La Cour 2004), and the previously mentioned studies on extraordinary and mystical experiences (Wulff 2000; Geels and Belzen 2003; Hood 2005). Our study drew on knowledge from those research fields and, in that sense, can be considered a bridge between them. Furthermore, our study falls into the phenomenological pragmatic tradition of William James, who described characteristics and 'fruits' of the religious experience rather than 'its roots' (James 1997, p. 34). That said, our research approach allows for more relational descriptions and incorporates more cultural practices than would be possible in James' view of religion as experiences of 'individuals in their solitude' (James 1997).

5 Geels has also done research on Islamic mysticism's experiential and behavioural aspects (Geels 2005), as well as those of Jewish mysticism (Geels 1998). 


\subsection{Christian Churches and Healing Practices in Norway}

In Norway, approximately $70 \%$ of the population belongs to the Church of Norway, which is a Lutheran denomination (Statistics Norway 2019). The number of members is slowly decreasing due to secularisation and increasing religious diversity; nonetheless, a majority of people in Norway use the Church for transitional rituals, particularly funerals. The number of people taking active part in Sunday services and other church activities is, however, much lower (Statistics Norway 2019), and only about $30 \%$ of the Norwegian population report believing in God (Karlsen et al. 2019). Approximately $7 \%$ of the Norwegian population are members of other Christian denominations, among which the Roman Catholic Church, the Pentecostal Church, and the Evangelical Lutheran Free Church have the highest numbers of members (Statistics Norway 2019). Additionally, there are about 250 migrant churches providing services in different languages. ${ }^{6}$ There are also congregations connected to evangelical mission organisations.. Both in the Church of Norway and in other denominations, healing practices can be found in one-to-one settings as part of the practice of pastoral care, as well as integrated in congregational services. Announced, open, and specific healing services are, however, scarce, both in the Church of Norway and in other denominations, including Pentecostal churches (Kleiven et al. 2019). There is also a reluctance among several people to speak openly about such experiences (Henriksen and Pabst 2013, p. 13) for fear of ridicule and being looked upon as naïve, mad, or too spiritual to fit in a secular Norwegian context (Nygaard et al. 2017). Thus, although a few congregations speak loudly about their healing practices, the Christian healing experiences in Norway often take place without much publicity (Henriksen and Pabst 2013, p. 28).

\section{Theoretical Perspective: 'The Lived Body'}

In understanding the participant's suffering and subsequent healing experiences, we have used the concept of the 'lived body', based on Maurice Merleau-Ponty's philosophy of the body (Merleau-Ponty 2002, pp. 77-232). 'The lived body' denotes the experienced body of the subject (Eriksen et al. 2019, p. 2). As an alternative to a dualistic Cartesian model in which the body is an object of substantiality (res extensa) that is opposed to thinking (res cogitans), Merleau-Ponty's model defines the body as an intending subject, as a pre/personal existence that constructs the world. Instead of the materiality of the body being separated from the lived experience, the body is seen as a hybridised synthesis. That is, the body is both an intending subjective consciousness and a material object. Merleau-Ponty (Merleau-Ponty 1968, pp. 130-55) used the term 'intertwining' to refer to the body as both intentionality and materiality, subject and object, lived and corporal. This is exemplified in the intertwinement of the sensation of touching-touched when one's hand (subject) touches other parts of the body (object), creating a 'double sensation' (Merleau-Ponty 2002, pp. 105-6).

Taking this anti-dualistic notion of the lived body into the medical realm, Leder (1992, p. 27) proposed a 'medicine of the intertwining'. He claimed that 'our notions of disease and treatment would always involve a chiasmatic blending of biological and existential terms, wherein these terms are not seen as ultimately opposed, but mutually implicatory and involved in intricate "logics" of exchange'. According to Leder $(1992,2019)$, the lived body provides a genuinely integrative framework. More than the term 'bio-psycho-social-spiritual' (Galanter 2010), in which the concepts are hyphenated or strung side by side, the notion of the lived body articulates these different aspects as being not only interrelated, but also intertwined. The lived body thus unifies the biological, psychological, sociological, and spiritual dimensions of illness. This intertwining means that our mode of being in the world (re)shapes our body in ways that influence health and illness. Accordingly, treatment is understood not as 'fixing the machine', but as addressing the lived body and its world relations (Leder 1992, p. 29).

6 https://kirken.no/nb-NO/om-kirken/slik-styres-kirken/mellomkirkelig-rad/okumenikk-og-kirkesamarbeid/ religionsdialog/integrering/. 
The Norwegian medical researcher and professor Anna Luise Kirkengen adhered to the same ideas of relating the philosophical-psychological theory of 'the lived body' to a health professional context. Echoing Leder, Kirkengen (2009, p. 33) underlined that the spiritual, mental, and physical aspects of human beings are not only interlinked, but also inherently inseparable and intertwined entities. The human being is thus understood as relational and integrated with its milieu as seen from a socio-cultural perspective (Kirkengen 2009, p. 69). This understanding emphasises the body itself as a living storyteller of past and present life experiences. Kirkengen's empirical research has been primarily concerned with how 'the lived body' reacts to sexual abuse in adolescence. Based on this research, she claims that negative life experiences, like abuse, are inscribed in the body and, as such, may contribute to diseases and illness later in life. These inscriptions, according to Kirkengen, are 'literal, graphical, etching-like' and permeated by unpleasant sensations (Kirkengen 2001, p. 8). In opposition to the biomedical model of disease, Kirkengen has concluded that biography and biology are indivisible (Kirkengen et al. 2013) and that 'human relationality is a medical topic' (Kirkengen 2001, p. 41).

Our study relied on this view of the lived body as a theoretical lens for exploring experiences of suffering, healing, and health. This lens allowed us to analyse how suffering and healing are expressed in reported physical, mental, social, and spiritual ailments, as well as in relationships and socio-cultural processes. Furthermore, as these aspects of the human person are seen as distinguishable, but not separate entities, we also explored how they are reported to be intertwined in the lived body through healing experiences (Merleau-Ponty 2002, p. 105).

\section{Material and Method}

\subsection{Recruitment and Sample}

To answer the research question, we recruited participants through our contacts among leaders of healing practices within Christian congregations and among leaders in diaconal institutions, as well as by snowball sampling using referrals from the participants. The final sample, which comprised the basis for this article, consisted of 19 women and 6 men, whose ages ranged from 23 to 72 years (see Table 1). The inclusion criteria were that (1) the informants themselves perceived their experiences as healing; (2) the informants related their experiences to Christian faith and practices; and (3) the healing event(s) was/were described as distinct turning point experiences.

The second criterion relied on the participants' own definition of what constituted Christian faith and practice. This way of circumscribing the sample led to the inclusion of two participants who combined their Christian faith with aspects of 'New Age spirituality of life' (Heelas 2008, p. 2), two participants who combined secular affiliation and faith with the use of Christian practice, and four conversion stories to Christianity. We were not able to construct the sample based on maximum variation of Christian denominational affiliation, as we had to pragmatically rely on our contacts, on religious leaders' knowledge of healing stories, and on informants' willingness to participate in the study. The combination of strategic and convenience sampling resulted in a final sample consisting of moderate religious diversity with an emphasis on Lutheran denominations (see Table 1). As a matter of convenience, the participants were selected from eastern, southern, and western regions of Norway. 
Table 1. The participants.

\begin{tabular}{|c|c|c|c|c|c|c|c|}
\hline No. & Pseudonym & $\begin{array}{c}\text { Age at } \\
\text { Time of } \\
\text { Interview }\end{array}$ & $\begin{array}{c}\text { Age at } \\
\text { Per-Ceived } \\
\text { Healing Event }\end{array}$ & $\begin{array}{l}\text { Religious } \\
\text { Affiliation }\end{array}$ & Reported Stressors & Perceived Healing Event & $\begin{array}{l}\text { Perceived Healing } \\
\text { Process/Outcome }\end{array}$ \\
\hline P1 & Signe & 29 & $20 \mathrm{~s}$ & $\begin{array}{l}\text { Pentecostal } \\
\text { Church }\end{array}$ & Death of father & Vision & $\begin{array}{c}\text { Consolation for grief } \\
\text { Renewed relationship with God }\end{array}$ \\
\hline P2 & Frida & 46 & $30 \mathrm{~s}$ & $\begin{array}{l}\text { Congregation } \\
\text { related to a } \\
\text { Lutheran mission } \\
\text { organisation }\end{array}$ & $\begin{array}{l}\text { Parental rejection } \\
\text { Depression } \\
\text { Suicide attempt }\end{array}$ & $\begin{array}{l}\text { Sense of power through } \\
\text { songs of praise }\end{array}$ & $\begin{array}{l}\text { New relationship with God } \\
\text { Conversion } \\
\text { Renewed relationship with self } \\
\text { and others } \\
\text { Increased self-value }\end{array}$ \\
\hline P3 & Mari & 27 & $20 \mathrm{~s}$ & $\begin{array}{l}\text { Evangelical } \\
\text { Lutheran Free } \\
\text { Church }\end{array}$ & $\begin{array}{l}\text { Parental rejection } \\
\text { High self-demands }\end{array}$ & $\begin{array}{c}\text { Vision } \\
\text { Internal bodily sensation } \\
\text { Touched by songs of } \\
\text { praise }\end{array}$ & $\begin{array}{c}\text { Renewed relationships with self, } \\
\text { parents, and God } \\
\text { Increased self-value }\end{array}$ \\
\hline P4 & Reidun & 48 & $40 \mathrm{~s}$ & $\begin{array}{l}\text { Mission Covenant } \\
\text { Church }\end{array}$ & $\begin{array}{l}\text { Parental rejection } \\
\text { Difficulties with } \\
\text { caring for foster } \\
\text { children }\end{array}$ & $\begin{array}{c}\text { Vision } \\
\text { Tactile sensation } \\
\text { Laying on of hands } \\
\text { Intercessory prayer }\end{array}$ & $\begin{array}{l}\text { Increased self-value } \\
\text { Power to look ahead }\end{array}$ \\
\hline P5 & Elisabeth & 48 & $40 \mathrm{~s}$ & $\begin{array}{l}\text { Ecumenical } \\
\text { fellowship }\end{array}$ & $\begin{array}{l}\text { Parental rejection } \\
\text { Fatigue } \\
\text { Anxiety } \\
\text { Depression }\end{array}$ & $\begin{array}{c}\text { Vision } \\
\text { Intercessory prayer }\end{array}$ & $\begin{array}{c}\text { Better physical health } \\
\text { Increased self-value } \\
\text { Renewed relationships with } \\
\text { parents and God }\end{array}$ \\
\hline P6 & Astrid & 50 & $40 \mathrm{~s}$ & $\begin{array}{l}\text { Mission Covenant } \\
\text { Church and an } \\
\text { international } \\
\text { charismatic } \\
\text { congregation }\end{array}$ & $\begin{array}{c}\text { Parental rejection } \\
\text { Lost job opportunity } \\
\text { Grief }\end{array}$ & Hearing of a voice & $\begin{array}{l}\text { Increased self-value } \\
\text { Release of grief } \\
\text { Increased energy }\end{array}$ \\
\hline P7 & Anita & 55 & $50 \mathrm{~s}$ & $\begin{array}{l}\text { Church of Norway } \\
\text { and an alternative } \\
\text { spiritual context }\end{array}$ & Cancer & $\begin{array}{c}\text { Vision } \\
\text { Laying on of hands } \\
\text { Internal bodily sensation }\end{array}$ & Healed from cancer \\
\hline
\end{tabular}


Table 1. Cont.

\begin{tabular}{|c|c|c|c|c|c|c|c|}
\hline No. & Pseudonym & $\begin{array}{c}\text { Age at } \\
\text { Time of } \\
\text { Interview }\end{array}$ & $\begin{array}{c}\text { Age at } \\
\text { Per-Ceived } \\
\text { Healing Event }\end{array}$ & $\begin{array}{l}\text { Religious } \\
\text { Affiliation }\end{array}$ & Reported Stressors & Perceived Healing Event & $\begin{array}{l}\text { Perceived Healing } \\
\text { Process/Outcome }\end{array}$ \\
\hline P8 & Ingrid & 50 & $30 \mathrm{~s}$ & $\begin{array}{l}\text { Non-affiliated and } \\
\text { a healing service in } \\
\text { Church of Norway }\end{array}$ & $\begin{array}{c}\text { Alcohol abuse in } \\
\text { family } \\
\text { Anger }\end{array}$ & $\begin{array}{l}\text { Non-contact laying on of } \\
\text { hands }\end{array}$ & Healed from anger \\
\hline P9 & Freddy & 60 & $50 \mathrm{~s}$ & Church of Norway & $\begin{array}{l}\text { Childhood } \\
\text { experiences of fear } \\
\text { Alcohol abuse } \\
\text { Loneliness }\end{array}$ & Internal bodily sensation & $\begin{array}{c}\text { Increased self-value } \\
\text { Stopped drinking } \\
\text { New relationships with } \\
\text { community, work, and God } \\
\text { Conversion }\end{array}$ \\
\hline P10 & Trine & 70 & $60 \mathrm{~s}$ & $\begin{array}{c}\text { Church of Norway } \\
\text { and an alternative } \\
\text { spiritual context }\end{array}$ & $\begin{array}{c}\text { Job loss } \\
\text { Fibromyalgia } \\
\text { Bodily collapse }\end{array}$ & $\begin{array}{c}\text { Vision } \\
\text { Internal bodily sensation } \\
\text { Laying on of hands }\end{array}$ & Increased energy \\
\hline P11 & Peter & 68 & $60 \mathrm{~s}$ & $\begin{array}{l}\text { Pentecostal } \\
\text { Church }\end{array}$ & Cancer & $\begin{array}{l}\text { Laying on of hands } \\
\text { Intercessory prayer } \\
\text { Inner voice }\end{array}$ & Healed from cancer \\
\hline P12 & Siri & 65 & $\begin{array}{c}\text { 60s (last } \\
\text { healing event) }\end{array}$ & $\begin{array}{c}\text { Church of Norway } \\
\text { and a Lutheran } \\
\text { mission } \\
\text { organisation }\end{array}$ & $\begin{array}{l}\text { Death of father } \\
\text { ME/CFS (Chronic } \\
\text { fatigue syndrome) } \\
\text { Depression }\end{array}$ & $\begin{array}{c}\text { Internal vision } \\
\text { Internal bodily sensation } \\
\text { Laying on of hands } \\
\text { Intercessory prayer }\end{array}$ & $\begin{array}{l}\text { Healed from depression } \\
\text { Still ME/CFS, but more energy }\end{array}$ \\
\hline P13 & Madiha & 42 & $\begin{array}{l}\text { 40s (last } \\
\text { healing event) }\end{array}$ & $\begin{array}{l}\text { Evangelical } \\
\text { Lutheran Free } \\
\text { Church }\end{array}$ & $\begin{array}{c}\text { Divorce } \\
\text { Hostile social } \\
\text { relationships } \\
\text { Pain in the back } \\
\text { and legs } \\
\text { Heart rhythm disorder }\end{array}$ & $\begin{array}{c}\text { Vision } \\
\text { Internal bodily sensation } \\
\text { Especially vivid dream } \\
\text { Touched by preaching } \\
\text { Sense of presence }\end{array}$ & $\begin{array}{l}\text { Increased self-worth } \\
\text { Increased energy }\end{array}$ \\
\hline P14 & Jasmine & 57 & $30 \mathrm{~s}$ & $\begin{array}{l}\text { Pentecostal } \\
\text { Church }\end{array}$ & Ulcer & $\begin{array}{l}\text { Non-contact laying on } \\
\text { of hands }\end{array}$ & Healed from ulcer \\
\hline
\end{tabular}


Table 1. Cont.

\begin{tabular}{|c|c|c|c|c|c|c|c|}
\hline No. & Pseudonym & $\begin{array}{c}\text { Age at } \\
\text { Time of } \\
\text { Interview }\end{array}$ & $\begin{array}{c}\text { Age at } \\
\text { Per-Ceived } \\
\text { Healing Event }\end{array}$ & $\begin{array}{l}\text { Religious } \\
\text { Affiliation }\end{array}$ & Reported Stressors & Perceived Healing Event & $\begin{array}{l}\text { Perceived Healing } \\
\text { Process/Outcome }\end{array}$ \\
\hline P15 & Ehete & 24 & $20 \mathrm{~s}$ & $\begin{array}{l}\text { Ethiopian } \\
\text { evangelical } \\
\text { migrant church }\end{array}$ & $\begin{array}{l}\text { Hostile social } \\
\text { relationships } \\
\text { Food poisoning } \\
\text { Negative visions }\end{array}$ & $\begin{array}{c}\text { Hearing of a voice } \\
\text { Vision } \\
\text { Internal bodily sensation } \\
\text { Laying on of hands } \\
\text { Intercessory prayer }\end{array}$ & Healed from negative visions \\
\hline P16 & Maria & 23 & $10 \mathrm{~s}$ & Church of Norway & $\begin{array}{c}\text { Hostile social } \\
\text { relationships } \\
\text { PTSD (post-traumatic } \\
\text { stress syndrome) after } \\
\text { flight to Europe } \\
\text { Suicidal } \\
\end{array}$ & $\begin{array}{l}\text { Intercessory prayer } \\
\text { Extraordinary natural } \\
\text { phenomenon }\end{array}$ & $\begin{array}{l}\text { Better mental health } \\
\text { Rescue from drowning in the } \\
\text { Mediterranean Sea }\end{array}$ \\
\hline P17 & Christian & 42 & $20 \mathrm{~s}$ & Church of Norway & $\begin{array}{l}\text { Childhood trauma } \\
\text { Low self-esteem } \\
\text { Drug abuse } \\
\text { Depression }\end{array}$ & $\begin{array}{c}\text { Internal bodily sensation } \\
\text { Mystical experience of } \\
\text { unity } \\
\text { Touched by preaching }\end{array}$ & $\begin{array}{c}\text { Increased self-value } \\
\text { Healed from drug abuse } \\
\text { New direction in life } \\
\text { New relationships with } \\
\text { community and God } \\
\text { Conversion } \\
\text { Internal power }\end{array}$ \\
\hline P18 & Caroline & 66 & $20 \mathrm{~s}$ & Church of Norway & $\begin{array}{l}\text { Sexual abuse as a child } \\
\text { Divorce } \\
\text { Migraine } \\
\text { Back and neck pain }\end{array}$ & $\begin{array}{c}\text { Hearing of a voice } \\
\text { Internal bodily sensation } \\
\text { Vision }\end{array}$ & $\begin{array}{c}\text { Renewed energy } \\
\text { Renewed relationship with God }\end{array}$ \\
\hline P19 & Charlotte & 43 & $20 \mathrm{~s}$ & $\begin{array}{l}\text { Pentecostal } \\
\text { Church }\end{array}$ & $\begin{array}{l}\text { Family violence } \\
\text { Mental illness during } \\
\text { childhood }\end{array}$ & $\begin{array}{c}\text { Hearing of a voice } \\
\text { Vision } \\
\text { Internal bodily sensations } \\
\text { Laying on of hands } \\
\text { Intercessory prayer }\end{array}$ & $\begin{array}{c}\text { Increased self-value } \\
\text { New meaning in life } \\
\text { New relationships with } \\
\text { community and God Conversion }\end{array}$ \\
\hline P20 & Kari & 70 & 12 & $\begin{array}{l}\text { Pentecostal } \\
\text { Church }\end{array}$ & $\begin{array}{l}\text { Fear of not going } \\
\text { to heaven }\end{array}$ & $\begin{array}{l}\text { Hearing of a voice or a } \\
\text { clear internal thought }\end{array}$ & Healed from religious anxiety \\
\hline
\end{tabular}


Table 1. Cont.

\begin{tabular}{|c|c|c|c|c|c|c|c|}
\hline No. & Pseudonym & $\begin{array}{c}\text { Age at } \\
\text { Time of } \\
\text { Interview }\end{array}$ & $\begin{array}{c}\text { Age at } \\
\text { Per-Ceived } \\
\text { Healing Event }\end{array}$ & $\begin{array}{l}\text { Religious } \\
\text { Affiliation }\end{array}$ & Reported Stressors & Perceived Healing Event & $\begin{array}{l}\text { Perceived Healing } \\
\text { Process/Outcome }\end{array}$ \\
\hline P21 & Adam & 19 & 12 & $\begin{array}{l}\text { Congregation } \\
\text { related to a } \\
\text { Lutheran mission } \\
\text { organisation }\end{array}$ & $\begin{array}{l}\text { Genetic multisystem } \\
\text { congenital disease }\end{array}$ & $\begin{array}{l}\text { Laying on of hands } \\
\text { Intercessory prayer } \\
\text { Hearing of a voice or clear } \\
\text { internal thought }\end{array}$ & Healed from genetic disease \\
\hline $\mathrm{P} 22$ & Torgeir & 58 & $\begin{array}{c}\text { 30s (last } \\
\text { healing event) }\end{array}$ & $\begin{array}{l}\text { Congregation } \\
\text { related to a } \\
\text { Lutheran mission } \\
\text { organisation }\end{array}$ & Back prolapse & $\begin{array}{l}\text { Laying on of hands } \\
\text { Intercessory prayer }\end{array}$ & Healed from back prolapse \\
\hline $\mathrm{P} 23$ & Gordon & 65 & $50 \mathrm{~s}$ & Church of Norway & Muscular pain & Laying on of hands & Relief of muscular pain \\
\hline P24 & Bodil & 55 & $40 \mathrm{~s}$ & Church of Norway & $\begin{array}{l}\text { ME/CFS (chronic } \\
\text { fatigue syndrome) }\end{array}$ & $\begin{array}{c}\text { Intercessory prayer from } \\
\text { a distance }\end{array}$ & $\begin{array}{c}\text { Gradual healing from ME/CFS } \\
\text { Increased energy }\end{array}$ \\
\hline P25 & Ina & 72 & $40 \mathrm{~S}$ & Church of Norway & Cancer & $\begin{array}{l}\text { Clear internal voice } \\
\text { or thought }\end{array}$ & Healed from cancer \\
\hline
\end{tabular}




\subsection{Data Collection}

Interviews took place between September 2016 and March 2020. A qualitative semi-structured interview format was used (Kvale and Brinkmann 2009) by which the participants were asked to describe (1) their healing experience(s); (2) what resources from Christian faith and practice they related to their experience(s); (3) what these experience(s) meant to them; and (4) how they made sense of their healing experience(s). Each of the three researchers conducted an almost equal number of interviews, which lasted from approximately 1 to $2 \mathrm{~h}$. Throughout the interviews, we aimed to retain an empathic interview style (Kvale and Brinkmann 2009, p. 148) to elicit sensitive stories, including some that the participants might have never shared before. The interviews were conducted at locations preferred by the participants, such as their homes, a café, or a church meeting room. Three interviews were conducted over telephone.

\subsection{Analysis}

The interviews were audiotaped, transcribed, and anonymised partly by the research team and partly by a research assistant. Applying thematic analysis (Braun and Clarke 2006) with a hermeneutical phenomenological approach (Smith et al. 2009) ${ }^{7}$, we first identified data from the material inductively while remaining aware of and discussing the possible impact of our initial projections. As the inductive, data-driven analysis showed that the participants' stories were built around the times before, during, and after the healing event, we first categorised and sorted the material into these three broad themes. Afterwards, we performed a more fine-grained analysis with an emphasis on participants' experiences during the healing event. This analysis showed that the participants narrated their bodily perceptions and reactions in different and often vivid ways. Thus, as a second phase, we applied the theoretical concept of the lived body as a 'focusing lens' (Dressman 2008, p. 69) in order to identify themes related to the participants' bodily experiences and to reduce the size of the data set. In order to strengthen the credibility of the data, the three researchers coded the material separately before comparing the identified themes and agreeing on the final thematic categorisation.

\subsection{Ethical Procedures}

The study was submitted to the Norwegian Centre for Research Data and received ethical approval prior to the interviews (project number 48840). All participants were informed of the purpose of the study prior to being interviewed and were required to sign an informed consent form before they could participate. Additionally, the participants were informed of their right to withdraw from the study at any time.

\subsection{The Participants}

Table 1 outlines the demographic variables, ages, assigned pseudonyms, and religious affiliations of the 25 participants, as well as characteristics of their healing experience(s). Details that could have jeopardised the anonymity of the participants were excluded or subsumed within broader categories.

\section{Results}

As mentioned above, the participants narrated their situations before, during, and after the healing event(s). Some participants structured their story chronologically; others arranged their story

7 We used Smith et al.'s (2009) approach to phenomenology, but did not fully follow their Interpretive Phenomenological Analysis (IPA), as it requires fewer cases. Phenomenology is concerned with the experiential appearance, and, in that sense, our study followed IPA in that it attempted to get as close as possible to the personal experiences of the participants. However, as in IPA, we recognise that such an endeavour is inevitably interpretative for both participants and researchers (Smith et al. 2009, p. 37). In line with Smith et al. (2009), we also included some linguistic aspects, which made us structure the participant's stories into the overarching themes. 
around certain themes or associations. However, it was common for all the participants to insert a narrative break in the story related to the healing event by using interjections such as, for example, 'suddenly ... ' (P19, P20) and 'then ... happened' (P1, P3, P6, P12, P13, P15, P17, P21). Some also reflected on the healing event as a turning point by using terms such as 'it was a change' (P2) or 'it was a before-and-after' (P5). In accordance with these articulations in the material, in reference to the aforementioned conceptualisation of healing experiences (Krippner and Achterberg 2000, p. 359), and with regard to the content of the participants' descriptions, we identified the following overarching categories: (1) the suffering lived body, which denotes stories about the participants' health and wellbeing prior to the healing event; (2) touching the lived body and (3) the touched lived body, which both conceptualise the healing event, i.e., what happened and how it was experienced, respectively; ${ }^{8}$ and (4) the healing lived body, which accounts for the participants' healing process after the healing event as well as their current situation.

\subsection{The Suffering Lived Body}

\subsubsection{Suffering with Emphasis on Difficult Relational Experiences}

Sixteen of the 25 participants linked their strain and suffering before the healing experience to difficult relational experiences in the past, particularly to their parents. They explored their past in terms of parents' 'rejection' (P4, P5, P6), 'lack of presence' (P3, P6, P9, P19), and 'lack of care' (P2), and they referred to parents' alcohol problems (P8, P2) and/or sexual abuse (P18, P19). Caroline said:

I experienced abuse, sexual abuse, as a child. And a psychologist has told me that already from birth, because I was born too early and was about to die without my mum being allowed to be there. I did not experience any close presence from when I was born eight weeks too early. Since I was born I have been in stress, both my body and my mind have been on constant alert. So my body is exhausted from constantly being alarmed. (P18 Caroline)

Two of the participants said that they had experienced difficult relationships later in life, in partnership and divorce (P13 and P18); another two participants referred to relations to religious authorities that had left them with anxiety about not being admitted to heaven (P17, P20); and three participants, who were migrants, discussed hostile social relations they had experienced in Norway after arriving (P13, P15, P16). Ehete, who is a migrant from Africa, explained her relational difficulty living in a new country in the following way:

And after I came to Norway, this was a very tough and difficult situation, especially you don't know people and it's totally different and you have none and you are very lonely, so I need God much more than the other times. And I prayed all night and I cannot even sleep, it was like crazy. (P15 Ehete)

As evident in the two excerpts above, these relational life experiences were considered to have caused pain and suffering in the lived bodies of the participants, with Caroline reporting that her body was 'worn out' and Ehete mentioning that she 'could not sleep'. The other participants who reported relational difficulties also described bodily suffering as, for instance, 'emotional pain' (P3, P5, P6), 'lack of energy' (P6, P24), 'strain in the body' (P9), or 'bodily collapse' (P10). Some also referred to a specific diagnosis, like ME/CFS (Chronic Fatigue Syndrome) (P19), anxiety with panic attacks (P17), depression (P2, P5, P12, P19), suicidal ideation (P2), fibromyalgia (P10), rheumatism (P9), and migraines (P18). Two of the participants noted that grief after the loss of a parent was the main source of their suffering before the healing event (P1, P10), and one referred to the loss of a career (P6). As evident in Table 1 , several of the participants mentioned multiple stressors.

8 What happened and how it is experienced are not possible to totally separate, but whereas the former attempts to answer the questions of who and where, the latter pays more attention to how. 


\subsubsection{Suffering without Emphasis on Difficult Relational Experiences}

Contrary to this relational pattern of the lived body, nine of the participants did not relate their suffering to difficult relations, childhood trauma, or grief. Of these participants, three reported having cancer (P7, P11, P25), one mentioned suffering from an ulcer (P14), one reported having a back prolapse (P22), two reported ME/CFS (P12, P24), one described being born with a genetic decease (P21), and one described having muscle and skeleton pain after excessive physical exercise (P23). Adam (P21), who had been ill up to the age of 12 , when he experienced the healing event, described his state by using medical diagnostic language.

The starting point was that I had a genetic disease that influenced me quite a lot. They said it was genetic because it affected more than four bodily systems. It was cardiovascular, brain, stomach, and musculature-and then they say that it is genetic, if it affects that much. I had muscular atrophy, cardiac fibrillation, frontal lobe epilepsy, immune deficiency. (P21 Adam)

This all-encompassing disease did, of course, affect his life and the lives of his family, thus making a strong inscription in Adam's lived body. However, he reported satisfaction with life and nurturing relations with his family and friends. Similarly, Bodil (P24) described a good relationship with her family in the midst of her illness, which, due to fatigue, had confined her to her bed. In contrast to Charlotte (P19), who, in her healing story, wove her ME/CFS ailment into her relational suffering, Bodil explained her ME/CFS diagnosis as developing from a sinusitis virus.

In summary, the participants reported a diversity of stressors and suffering prior to their healing event. A majority of the pain was linked to difficult relational experiences, either in childhood or later in life. However, some participants reported good childhood and present-life relationships, pointing instead to suffering from targeted medical diseases. In both groups, the pain was described qualitatively in their own words, but also, by some, through the use of identified diagnoses. The degree to which the ailments were described as intertwined bio-psycho-social-spiritual differed. On the one end of what can be seen as a continuum were narratives in which the bio-medical and the relational/psychological/social were closely connected (such as P15 and P18). On the other end were narratives that solely expressed one aspect of the lived body (such as P23).

\subsection{Touching the Lived Body}

In analysing the participants' stories of what happened during their healing events, we found that these moments, in different ways, could be characterised as someone or something touching the lived body. We further identified that such touching could take place both with and without other human beings being present and at a spectrum of physical distance-closeness and perceptual space.

\subsubsection{Healing Events as Encounters}

Seventeen of the healing stories emphasised that other people, such as a healer or a pastor, a congregation member, or a friend, were present during the healing event and engaged with the participants through prayer, by reading from the Bible, or via rituals. These relational practices could be specific healing practices in which the participants took part to intentionally seek healing of their ailments (P7, P8, P12, P14, P15, P21, P22, P23, P24), or they could be more general practices of prayer, preaching, and rituals (P3, P4, P5, P10, P11, P13, P16, P17) that, more or less surprisingly, were experienced as healing by the participants.

However, other participants did not take part in relational healing practices. They were alone during the healing event, or they were with people who did not play an active role in the healing event. One example was Astrid (P6), who was going for a walk by herself on her lunch break when she suddenly heard a voice.

Suddenly I feel that I hear God-and this is not something I usually do. 'Now the post that you wished for 20 years ago is vacant.' I wondered if something was wrong. I finished my 
walk, and the first thing I did when I came back to work was to turn on my computer, look up this orchestra [where she had wished to work as a musician], and I thought this is nonsense, right? But then it was a job advertisement, for the post I had wanted 20 years ago. It was posted on that day. It was actually vacant.

Extraordinary visions and voices, like the voice Astrid perceived she had heard, could also happen in the human relational healing practices, before, during, or right after human touch. Take, for example, Anita (P7), who had a vision of an angel standing beside her couchwhen a healer held her hands around her ankles during a healing session, or Adam (P21), who heard an extraordinary inner voice some hours after he had taken part in intercessory prayer.

Both in the practices in which other people were involved and when the participants had their experiences alone, the touch was interpreted as an encounter with God-except in the two cases of participants with secular orientation (P8, P23). Perceiving the touch as initiated by God did not mean that they saw their own role, or the role of the healer, as totally passive. Astrid (P6), who was surprised by the experience, said: 'I feel I have experienced that God was sovereign in helping me, on his own initiative, and he restored my grief. But I also think it has to do with me leaning on him' (interpreted as God).

\subsubsection{Healing Events in Physical and Perceptual Space}

Several of the participants experienced their healing event by the laying on of hands, which was either accompanied by intercessory prayer (P4, P11, P12, P15, P12, P14, P19, P21, P22) or occurred without any prayer (P7, P23). Touch by hands was described either as the physical contact of laying on of hands (P4, P7, P11, P12, P15, P17, P19, P21, P22, P23) or as non-contact laying on of hands (P8, P12, $\mathrm{P} 14)$, in which the healer operated at some distance. For instance, Ingrid (P8) described how a healer had held her hands close to Ingrid's head, moving them down her head without actually physically touching her. Reidun (P4) experienced the laying on of hands in a prayer session at a service in her local church. She explained that those who wished to be prayed for were asked to come forward, and that someone she knew approached her and put her arm around her, which made Reidun feel a very 'strong heat'. Other participants described the healing event as touch in a less concrete, physical way. They experienced being emotionally touched when, for instance, a pastor read some words-often from the Bible - or through particular songs in a service. Madiha (P3) felt strongly touched when a preacher proclaimed 'the name of Jesus' and the words 'sunk down in [her] heart', stating that 'it was then it happened [the healing event]'. Frida (P2) explained that songs of praise 'touched' her and 'broke down and penetrated walls'. Bodil (P24) experienced healing that she ascribed to prayer from an even longer distance. While being confined with ME/CFS, she had asked for intercessory prayer in a bulletin distributed to a prayer network. She did not know when the people in the network were praying, nor did she hear or see those who were praying. However, she felt a remarkable remission, also affirmed by the doctor, shortly after the distribution of the bulletin.

Extraordinary perceptions, which could be experienced both with and without human touch, were described as visions and voices (P1, P3. P4. P5, P6, P7, P10, P5, P12, P13, P15, P18, P19), experiences of unity (P17), a sense of presence (P1, P7, P13, P15, P17, P18, P19), sudden clear thoughts (P21, P25), and extra vivid dreams (M3). Some participants were clear that their experience was either 'inner', like an 'inner vision/picture' (Elisabeth P5), or 'outer', like Charlotte (P17), who emphasised that she could hear the voice 'physically and not inside me'. However, several of the participants were not clear about whether their perceptions were 'inner' or whether they had experienced them through their senses. Kari (P20) said 'I cannot remember if I heard a voice or if it was inside me'. Peter (P11), who identified a clear inner voice, explained it this way:

But I experienced it in a very special way, that God spoke to me at the doctor's office: 'Don't be afraid. Just believe'. The experience of God saying this to me, in that situation, was so distinct, so I thought: 'Now this is God speaking with me'. It is not just a word I take out of 
the air or have memorised or something I say to myself out of fear. It came to me. Almost as distinct as the doctor's voice. It was not an audible voice, but still just as distinct. (P11 Peter)

Regardless of the physical and perceptual space, and irrespective of the presence or non-presence of humans, the participants experienced a powerful touch that made a transformative impact on their lived body.

\subsection{The Touched Lived Body}

\subsubsection{Touch as Energetic Experience}

The touch mediated through other people's laying on of hands, from readings and hymns, and from extraordinary visions and voices was distinctly felt in the lived bodies of the participants. It was often described in energetic terms, as power, energy, strength, light, and warmth. Freddy (P9), expressed how he felt 'warmth, tingling, and burning' and 'bubbles coming upward'. He also described the healing event as filled by light, and that he felt 'enlarged and lifted'. Trine (P10) experienced a 'waterfall of light sprinkling through her'. Peter (P11) envisioned that he was wrapped in cotton and felt he was 'carried' by someone. Christian (P17) sensed energy and that he was 'glowing as a heater lamp'. Reidun (P4) felt 'warmth streaming through her whole body', and Gordon said that the healer's touch spread warmth 'radiating up his leg'. The energetic experiences could, however, also be described as the feeling of calm, of inner peace and quietness (P1, P4, P5, P7, P10, P13, P17, P18, P19, P25), or, as Caroline (P18) put it: 'I was weightless as a space traveller' (P18 Caroline).

Several of the informants used metaphors to express how they were feeling. Charlotte (P19), who was not familiar with Christianity at the time of the healing event, described a vision during a friend's prayer for her as 'waves', 'waterfall', and 'rain' that were 'flowing through her':

Suddenly, it was like the whole flat ... . such a profound presence of love entered. It was as if I saw love as rain.. Then it came upon me.. And then it started to flow through me. And I just started to cry really hard. It was like there were waves upon waves of love, like a waterfall. And that love washed away all the emptiness, all the 'Why are you here? You are not loved'. It was like my whole universe was suddenly transformed. It was as if everything just fell into place.

As in this quotation from Charlotte, it was not always clear from the healing stories whether the participants had actual visions of, for instance, a waterfall, or whether they instead used it as a metaphor later on to better describe an otherwise ineffable bodily experience of energy. The difference could be blurred or overlapping, like when Charlotte said she 'saw love as rain-and it came upon me'.

\subsubsection{Touch as Experience of Love}

Not all, but many of the participants, like Charlotte, experienced the energy and power during the healing event as love, interpreted as coming from God. Siri (P12) said she was 'surrounded by a totally perfect love', which was 'very strong' and difficult to put into words. Others expressed that they were 'seen' (Elisabeth P5),'embraced' (Madiha M3), or 'wrapped up' (Astrid P6) in 'God's presence' (Signe P1, Ehete P15, Anita P7) and restored in their broken relations to other people or in themselves. They described a relationship to what they understood as God as a close relationship. Christian (P17) said:

... My experience of a higher power, of God, ... it's like a very strong intimacy. It's as if someone is very close to me ... as kindness and warmth.

Christian concluded that his experienced love from God was a power he could bring with him, especially in difficult times. 


\subsubsection{Touch as Emotional Release}

The healing events often resulted in immediate emotional expressions, described as crying (particularly underscored by P1, P2, P5, P6, P8, P19, and P22). For example, Frida (P2), in her conversion story, explained how songs of praise 'penetrated walls' that she had set up and led to her deeply crying, as the songs expressed 'such a touch, functioning detrimentally to the pain'.

Astrid (P6), who heard a voice telling her about the vacant musician post and who later heard the same voice asking her if she really wanted to take up her career, narrated:

... and I cried and cried and cried for an hour, sat and laid at the kitchen table and just poured out all the grief. At the same time I felt totally wrapped up in God's presence, it was love. And my husband came, and I told him what had happened and we cried together, and it was such a clear restoration for me.

Ingrid (P8), who experienced non-contact laying on of hands from a healer, said she suddenly started to 'cry the eyes out', feeling 'released' from her anger right afterwards, and we have already seen how Charlotte cried really hard after her visions and voices. In this respect, touch seemed to have power to release tears and restrained feelings.

\subsubsection{Touch as Hitting the Target}

Another characteristic of touch was that it was perceived as hitting the target of the participant's burden. They were touched right at the centre of their embodied pain, often in surprising ways. Some participants perceived that identifying the target was more than what was possible for people to know. Torgeir (P22), who suffered from a painful back prolapse, experienced that a healer, who was present at a congregational service, received 'exact knowledge' that someone with back pain was present in the room. When Torgeir was consequently prayed for, he experienced a sudden healing of his pain. Elisabeth (P5), who was separated from her parents as a new-born child and subsequently experienced parental rejection, received a surprising inner vision during an intercessory prayer:

When they prayed for me, I got such a vision. It was just an inner vision and it was beautiful. It was that I saw, in a way, God's hands, and then he holds me like a baby, and I was wrapped in white cloth. And then I don't see him, but I see my own face. The biggest smile you can ever have. And in my smile, I not only saw that I was secure, but I was very enthusiastic and expectant.

Elisabeth underscored that 'this was experienced as the deepest healing and life-transforming experience in relation to the deep, deep rejection that I experienced as a little child'. Both those who took part in distinct healing practices, those who attended general Christian practices, and those who had more spontaneous experiences expressed that the healing experience was, in a way, hitting the target of their pain, which meant that it had a great impact on their lived bodies.

\subsection{The Healing Lived Body}

\subsubsection{Healing as 'Wholerness'}

One of the informants, Adam (P21), experienced radical healing in which he fully recovered from his genetic illness. Some hours after an intercessory prayer, at the age of 12 , he felt a very strong compulsion to eat food he previously was not capable of eating without turning very ill. He was able to digest the food without any reaction or need for hospitalisation, which normally would have occurred. After that, he started to grow stronger; his physiotherapist surprisingly confirmed that his muscles had grown, he could leave his wheelchair, and he is now, at the age of 19, feeling healthy. Similarly, Jasmine (P14), who had a stomach ulcer, said she recovered fully after the pastor had prayed for her. Kari (P20), who had experienced religious anxiety as a child, was restored from that burden. 
However, most of the participants described the healing event as the start of a new process, not necessarily an endpoint. For most of the participants, the healing event was also reported to initiate a healing process that changed or eased some parts in their lived body, whilst other parts were still painful. Elisabeth, who described the healing as giving her 'enormously more capacity' and said that she now was 'raising up and living', also underscored that the process had not ended. She succinctly emphasised:

... becoming whole is not done quickly, and I dare not say that I have become whole either, but I am for sure on the way to becoming more whole'. (P5 Elisabeth)

Siri (P12), who was suffering from depression and ME/CFS, and who felt that in the healing event, 'something was physically taken off from her shoulders', described her healing as being 'lifted out of depression'. Her depression was dissolved. Her ME/CFS, however, did not disappear, but she managed to do more; for instance, hosting a new year party, which she was previously incapable of doing. Christian reflected that even though life has ups and downs, and despite sometimes feeling worthless, the power he received was not gone. Charlotte (P19) explained how being touched by 'power and light' had catalysed a radical new start in her life: 'It was the start of deep, deep processes in myself'.

Thus, although a few of the participants said that they fully recovered and were healed from their suffering, most described their healing as an ongoing process. They further considered themselves as 'more whole' or 'wholer', rather than 'whole'.

\subsubsection{Healing in the Lived Body}

As we have seen, the healing event, with its powerful bodily experiences, propelled a change in the participants' lived bodies, one which expanded in different ways; mitigating pain, increasing wellbeing, curing deceases, but also as restoring relations with themselves, with others, and with their God. Madiha (P13) emphasised that the healing experience 'went into my whole body' and that it 'strengthened me'. Reidun said she started to 'accept herself'. Christian emphasised that he had 'peace' with himself. Several of the participants said they had become 'closer to people' (P2, P5, P9, P17, P19) after the healing event, and that they had 'taken new steps' (P5 Elisabeth). For some of the participants, the healing event affected the lived body in all its aspects and relations. It also affected their orienting system and gave new lived meaning, a 'feeling of direction' (P9 Freddy). For others, the reported impact was limited to a certain body part, like, for instance, Gordon (P23), who was healed from his back pain and did not talk about radical relational changes, change in personality, or change in his secular orientation. However, for all the participants, their healing experience was woven into their illness and health stories, which were embedded in their relational and socio-cultural life.

\section{Discussion}

\subsection{Religious Healing Experiences as Re-Inscriptions in the Lived Body}

The aim of the present study was to characterise diverse cases of extraordinary religious healing experiences related to Christian faith and practices. In light of the concept of the lived body, as operationalised by Kirkengen $(2001,2009)$ and Leder $(1992,2019)$ into a health professional field, we examined how the bio-psycho-social-spiritual dimensions manifested in the narrated healing experiences of the participants. Our findings suggest that several of these dimensions were present in most of the participants' reported experiences of suffering. The aspects seemed to be intertwined in, for instance, relational difficulties, low self-value, and lack of energy. These cases of suffering can be interpreted in light of the negative inscriptions made by poisonous relationships, as described by Kirkengen (2001, p. 8) and, accordingly, be seen as manifest in intertwined bodily, mental, and relational ailments. 
However, some participants primarily described their suffering in terms of biomedical diagnoses. In the cases of reported diagnoses that were not linked to relational or mental difficulties, such as back pain after hard exercise or congenital genetic disease, the intertwined perspective was not prominent. There may have been limitations to the interviews because we did not ask specifically about human relationships. Yet, intertwinement could be found in the participants' healing stories. Contrary to Kirkengen's (2001) research focusing on poisonous childhood experiences that are inscribed in the lived body and have impacts on health later in life, some participants pointed instead to nurturing, close relationships that were not contributing to their suffering but, instead, were a positive part of their healing experiences.

In addition, the participants' relationships with God before and during the healing event seemed to be of importance to most of their healing experiences. This resonates with studies emphasising the relational aspects of healing. For instance, loving images of God have been related to higher self-esteem (Birgegard and Granqvist 2004). Furthermore, it has been suggested that religious and spiritual healing practices can contribute to healing in a way that parallels psychotherapy's relational contribution to psychological healing (Watts 2011, p. 3). In a previous publication (Nygaard et al. 2020), we analysed nine of the 25 interviews in light of psychological attachment theory, arguing that God may serve as an attachment-like figure (Granqvist and Kirkpatrick 2013) in the healing process. We suggested that increased secure attachment (earned security) may have been obtained through the healing event, which, in these cases, was described as love-providing and targeted, featuring God as loving and omnipotent. This earned security could further be seen as having healing potential in the participants' relationships with themselves, their families and friends, and God. However, in analysing all 25 interviews, as we did in this article, we found that a few participants with a secular orientation did not narrate their healing experiences in such a way that could be interpreted as providing loving images of God, and some did not seem to experience a change in their attachment style. Nevertheless, based on the stories we have analysed, we can say that the attachment perspective can form a partial understanding (not a causal explanation) of the relational aspect of the powerful touch of the healing event.

In addition to this relational understanding related to the characterisation of the healing event as love-providing, a salient point in the interviews was the emphasis on energy experiences. Both when being physically touched by other human beings and when feeling touched by songs, preaching, or extraordinary encounter experiences, the participants described a strong embodied sense of power and energy. Expanding on Lundmark's (2020) categorisation of extraordinary experiences, our findings emphasise not only the visual or auditory character of such sensations and imaginations, but also their energetic character, which seems to have played a role in the participants' perceived powerful transformations. Some participants emphasised that they had the power with them in all their relationships. Others said they could go back and re-experience the feeling of power. In summary, the 25 healing stories had different combinations of relational and energetic experiences that created a distinct 'turning-point' experience, which started a new process in the participants' lived bodies.

As we have seen, Kirkengen (2001, p. 8) argued that difficult experiences may create inscriptions in the lived body. Kirkengen (2017) consulted biomedical research showing that abusive relations leave visual and tactile imprints in the brain that mirror the poisonous experiences and disrupt the body's organs, tissues, cells, and genes. Our phenomenological material does not provide access to the participants' medical records. Yet, we can ask whether religious healing events can be interpreted as re-inscriptions in the sense that they are experienced as transformative imprints in the intertwined lived bodies through different forms of touch. The stories of the 25 participants in our study reveal powerful experiences of transformation. Although the healing experience for most of them was seen as processual, the healing event of (often) short duration nevertheless made a distinct impact that promoted improvements to their health. Based on the stories of these 25 participants, we argue that the experienced healing events, which we have characterised as involving the sense of a powerful 
touch that is targeted, energetic, emotional, and love-providing, can be hermeneutically conceptualised as re-inscriptions that affected the lived body and spurred renewed health and lived meaning.

\subsection{Religious Healing Experiences beyond Distinct Healing Practices}

Through our sampling of diverse cases, we found that healing events are characterised not only by defined healing practices, such as intercessory prayer and the laying on of (warm) hands, but also by more general religious practices that were experienced as healing, as well as by spontaneous visions, voices, peculiar inner thoughts, and sensations. These encounter experiences (White and Brown 2000) appeared in tandem with defined and general healing practices, but also as independent experiences with a transformative healing function. This finding resonates with our pilot study (Nygaard et al. 2017), in which five of the six participants reported encounter experiences as the main characteristic of the healing event. It also resonates with several studies that emphasise transformation after extraordinary encounter experiences and mystical experiences (Geels 2014; Wulff 2000). Our findings suggest that healing experiences, as defined in this article and as defined by White and Brown (2000), may overlap with or be a continuation of encounter experiences and mystical experiences. It is thus fruitful to study them together to better understand how these experiences can have such a powerful impact on people's health and wellbeing.

\subsection{Strengths, Limitations, and Clinical Implications}

Although we could have wished for even greater diversity in healing practices across Christian denominations, the strength of the present study rests in its selection of diverse cases, yielding a broad characterisation of extraordinary healing experiences related to Christian faith and practices. However, the hermeneutic-phenomenological approach, broad sampling, and analysis based on retrospective interviews imposed limitations on what could be said to (causally) explain why these moments of short duration can have a healing impact on people's lives. As research on healing experiences in the field of psychology of religion is scarce, further research using a combination of qualitative, quantitative, longitudinal, and experimental approaches is encouraged. Moreover, narrative approaches would shed further light on the relation between discourses in the participants' religious milieus and experiences of healing.

All but one of the participants in our sample reported positive experiences of healing practices, although we encouraged them to include negative experiences in their stories, if relevant. This positive framing does not mean that we are unaware that healing practices are potentially damaging, whether experienced spiritually or physically. The practice of 'touch', which was found to be central in the healing stories, is sensitive to abuse and, as revealed in our previous paper on announced healing practices in light of power theories, some healing practitioners fail to follow up with the participants who may experience broken hopes (Kleiven et al. 2019). Notwithstanding these concerns, in a clinical sense, our contribution has been to provide concepts that characterise positive healing stories and that often remain unspoken. While our previous pilot study (Nygaard et al. 2017) found that the participants struggled to explain and find exact words to describe their healing experiences, this article contributes by analysing experienced bodily knowledge that, to many, is ineffable and unknown (Uotinen 2011).

Author Contributions: Conceptualization, A.A., M.R.N. and T.K.; Methodology, A.A., M.R.N. and T.K.; Validation, A.A., M.R.N. and T.K.; Formal Analysis, A.A., M.R.N. and T.K.; Data Gathering, A.A., M.R.N. and T.K.; Writing-Original Draft, A.A.; Writing-Review \& Editing, A.A., M.R.N. and T.K.; Project Administration, A.A. All authors have read and agreed to the published version of the manuscript.

Funding: This research received no external funding.

Conflicts of Interest: The authors declare no conflict of interest. 


\section{References}

Ammerman, Nancy Tatom. 2013. Sacred Stories, Spiritual Tribes: Finding Religion in Everyday Life: Finding Religion in Everyday Life. New York: Oxford University Press.

Belzen, Jacob A. 2010. Towards Cultural Psychology of Religion: Principles, Approaches, Applications. Dordrecht: Springer. Birgegard, Andreas, and Pehr Granqvist. 2004. The correspondence between attachment to parents and God: Three experiments using subliminal separation cues. Personality and Social Psychology Bulletin 30: 1122-35. [CrossRef] [PubMed]

Braud, William. 2012. Health and Well-Being Benefits of Exceptional Human Experiences. In Mental Health and Anomalous Experience. Edited by Graig Murray. New York: Nova Science Publishers, pp. 107-24.

Braun, Virginia, and Victoria Clarke. 2006. Using Thematic Analysis in Psychology. Qualitative Research in Psychology 3: 77-101. [CrossRef]

Brown, Candy Gunther. 2012a. Studying Divine Healing Practices: Empirical and Theological Lenses, and the Theory of Godly Love. PentecoStudies 11: 48-66. [CrossRef]

Brown, Candy Gunther. 2012b. Testing Prayer: Science and Healing. Cambridge: Harvard University Press.

Cardeña, Etzel, Steven Jay Lynn, and Stanley Krippner. 2000. Varieties of Anomalous Experience: Examining the Scientific Evidence. Washington: American Psychological Association.

Dein, Simon, and Roland Littlewood. 2007. The Voice of God. Anthropology \& Medicine 14: 213-28.

Dressman, Mark. 2008. Using Social Theory in Educational Research: A Practical Guide. New York: Routledge.

Eriksen, Thor Erik, Cassandra Falke, and Espen Dahl. 2019. Phenomenology of the Broken Body. New York: Routledge Research in Phenomenology. [CrossRef]

Galanter, Marc. 2010. Spirituality in Psychiatry: A Biopsychosocial Perspective. Psychiatry 73: 145-57. [CrossRef]

Geels, Antoon. 1998. Judisk Mystik: Ur Psykologisk Synvinkel. Jewish Mysticism. From a Psychological Viewpoint. Skellefteå: Norma.

Geels, Aantoon. 2001. Förvandlande Ögonblick: Gudsuppenbarelser i vår Tid. Transformative Moments. Revelations of God in Our Time. Skellefteå: Norma.

Geels, Antoon. 2005. Muslimsk Mystik: Ur Psykologisk Synvinkel. Islamic Mysticism: From a Psychological Viewpoint. Skellefteå: Norma.

Geels, Antoon. 2014. Mystikk og religionspsykologi. Mysticism and Psychology of Religion. In Religionspsykologi. Edited by Lars Danbolt, Leif Gunnar Engedal, Knut Hestad, Lars Lien and Hans Stifoss-Hanssen. Oslo: Gyldendal Akademisk, pp. 217-29.

Geels, Antoon, and Jacob A. Belzen. 2003. Transforming Moments-A Psychological Perspective on Religious Visions: Contemporary and Historical Cases. Amsterdam: Rodopi.

Geels, Antoon, and Owe Wikström. 2006. Den Religiösa Människan: En Introduktion till Religionspsykologin. The Religious Human Being. An Introduction to Psychology of Religion. Stockholm: Natur \& Kultur, vol. 5.

Granqvist, Pehr, and Lee A. Kirkpatrick. 2013. Religion, Spirituality and attachment. In APA Handbook of Psychology, Religion and Spirituality. Washington, DC: American Psychologocal Assosiation, vol. 1, pp. 139-55.

Gutierrez, Ian A., Amy E. Hale, and Crystal L. Park. 2018. Life-Changing Religious and Spiritual Experiences: A Cross-Faith Comparison in the United States. Psychology of Religion and Spirituality 10: 334-44. [CrossRef]

Heelas, Paul. 2008. Spiritualities of Life: New Age Romanticism and Consumptive Capitalism. Malden: Blackwell Publ. Henriksen, Jan-Olav. 2016. Jesus as Healer: A Gospel for the Body. Grand Rapids: Eerdmans Publishing Company. Henriksen, Jan-Olav. 2018. Varme Hender. Warm Hands. Oslo: Verbum.

Henriksen, Jan-Olav, and Kathrin Pabst. 2013. Uventet og Ubedt: Paranormale Erfaringer i Møte Med Tradisjonell Tro. Unexpected and Not Asked for: Paranormal Experiences in Traditional Faith. Oslo: Universitetsforlaget.

Hood, Ralph W. 2005. Mystical, Spiritual, and Religious Experiences. In Handbook of the Psychology of Religion and Spirituality. Edited by Raymond. F. Paloutzian and Crystal L. Park. New York: The Guildford Press, pp. 348-64.

Hood, Ralph W. 2012. Commentary to the special issue of the arthive for the psychology of religion on "spirituality". Archive for the Psychology of Religion 34: 105-11. [CrossRef]

Hovi, Tuija. 2015. Localising and Acculturating the Global: The Healing Rooms Prayer Service Network in Finland. Approaching Religion 5. [CrossRef]

Hovi, Tuija, and Herman Westerink. 2013. Meanings of Healing: Experiences of Prayer-Team Members at the Christian Healing Rooms Service in Finland, 1st ed. Göttingen: V\&R Unipress, vol. 4. 
Hvidt, Niels Christian. 2002a. Helgenkåring, undersøgelse af mirakler og virkning av forbøn. Canonization of Saints, Investigation of Miracles and the Effect of Intercession. Tidsskrift for Religionslærerforeningen for Gymnasiet Og HF. Available online: https://www.hvidt.com/hvidt.com/default978b.html?page=pub\&CatHead=57\& CatMain $=58 \& \mathrm{IDF}=91 \&$ sortset $=$ default $\&$ pagenum $=4 \&$ show $=$ text $($ accessed on 28 October 2020).

Hvidt, Niels Christian. 2002b. Mirakler: Møder Mellem Himmel Og Jord. Miracles: Encounters between Heaven and Earth. København: Gyldendal.

James, William. 1997. The Varieties of Religious Experience: A Study in Human Nature. Touchstone: Simon \& Schuster Inc. Jors, Karin, Arndt Büssing, Niels Christian Hvidt, and K. Baumann. 2015. Personal Prayer in Patients Dealing with Chronic Illness: A Review of the Research Literature. Evidence-Based Complementary and Alternative Medicine. [CrossRef]

Kaptchuk, Ted J. 2002. The Placebo Effect in Alternative Medicine: Can the Performance of a Healing Ritual Have Clinical Significance? Annals of Internal Medicine 136: 817. [CrossRef]

Karlsen, Gry, Bodil Agasøster, and Knut Kalgraff Skjåk. 2019. Survey on Religion, Norwegian Part of ISSP, 2018. Bergen: Norwegian Center for Research Data. [CrossRef]

Kirkengen, Anna Luise. 2001. Inscribed Bodies: Health Impact of Childhood Sexual Abuse. Dordrecht: Kluwer.

Kirkengen, Anna Luise. 2009. Hvordan Krenkede Barn Blir Syke Voksne. How Abused Children Become Ill Adults. Oslo: Universitetsforlaget.

Kirkengen, Anna Luise. 2017. Diagnose: Barndomsforgiftning. Diagnosis: Childhoospoisening. Tidsskrift for Psykisk Helsearbeid 14: 16-24. [CrossRef]

Kirkengen, Anna Luise, Tor-Johan Ekeland, Linn Getz, Irene Hetlevik, Edvin Schei, Elling Ulvestad, and Arne Johan Vetlesen. 2013. What Constitutes Competence? That Depends on the Task. Scand J Prim Health Care 31: 65-66. [CrossRef] [PubMed]

Kirkpatrick, Lee A. 2005. Attachment, Evolution, and the Psychology of Religion. New York: Guilford Press.

Kleiven, Tormod, Anne Austad, and Marianne Rodriguez Nygaard. 2019. Maktdynamikk og sårbarhet; fellesskap som inviterer til helbredelse. Vulnerability and the Dynamics of Power: Congregations Inviting to Healing. Tidsskrift for Praktisk Teologi 35: 74-86.

Koenig, Harold Georg, Dana E. King, and Verna B. Carson. 2012. Handbook of Religion and Health, 2nd ed. New York: Oxford University Press.

Krippner, Stanley, and Jeanne Achterberg. 2000. Anomalous Healing Experiences. In Varieties of Anomalous Experience: Examining the Scientific Evidence. Edited by Etzel Cardeña, Steven Jay Lynn and Stanlay Krippner. Washington, DC: American Psychological Association, pp. 353-96.

Kvale, Steinar, and Svend Brinkmann. 2009. Interviews: Learning the Craft of Qualitative Research Interviewing, 2nd ed. Los Angeles: Sage.

La Cour, Peter. 2004. Forholdet mellem religion og helbred. The relation between faith and health. In Kan Tro Flytte Bjerge? Om Religion Og Helbred. Can Faith Move Mountains? Edited by N. C. Hvidtand and C. Johansen. København: Gyldendal, pp. 120-34.

La Cour, Peter, and Niels Christian Hvidt. 2010. Research on meaning-making and health in secular society: Secular, spiritual and religious existential orientations. Social Science Medicine 71: 1292-99. [CrossRef]

Leder, Drew. 1992. A Tale of Two Bodies: The Cartesian Corpse and the Lived Body. In The Body in Medical Thought and Practice. Philosophy and Medicine. Dordrecht: Springer, vol. 43.

Leder, Drew. 2019. Re-possibilising the World. Recovery from Serious Illness, Injury or impairment. In Phenomenology of the Broken Body. Edited by Thor Eirik Eriksen, Cassandra Falke and Espen Dahl. New York: Taylor and Francis, pp. 173-87.

Luhrmann, Tanya M. 2012. When God Talks Back: Understanding the American Evangelical Relationship with God. New York: Alfred A. Knopf, vol. 38.

Lundmark, Mikael. 2010. When Mrs B Met Jesus during Radiotherapy. A Single Case Study of a Christic Vision: Psychological Prerequisites and Functions and Considerations on Narrative Methodology. Archive for the Psychology of Religion 32: 27-68. [CrossRef]

Lundmark, Mikael. 2016. Suffering for Others as Religious Meaning-Making: Varieties, Prerequisites, and Functions in the Coping Process of a Sample of Practising Christians Living with Cancer. Mental Health, Religion $\mathcal{E}$ Culture 19: 522-37. [CrossRef] 
Lundmark, Mikael. 2017. Religiositet Och Coping: Religionspsykologiska Studier av Kristna Med Cancer. Religiosity and Coping: Studies of Christian People with Cancer, within the Framework of Psychology of Religion. Umeå: Umeå Universitet.

Lundmark, Mikael. 2020. Guds rekvisita: Religionspsykologiska och teologiska fallstudier av materiella dimensioner vid upplevelser av gudsmöten på Norrlands universitetssjukhus. In Rituella Rum Och Heliga Platser. Ritual Rooms and Sacred Places. Skellefteå: Norma, pp. 189-216.

McGuire, Meredith B. 2008. Lived Religion: Faith and Practice in Everyday Life. Oxford: Oxford University Press.

Merleau-Ponty, Maurice. 1968. The Visible and the Invisible. Evanston: Northwestern University Press.

Merleau-Ponty, Maurice. 2002. Phenomenology of Perception. London and New York: Routledge Classics.

Nygaard, Marianne Rodriguez, Anne Austad, and Tormod Kleiven. 2017. Helende erfaringer og den levde kroppen. Vendepunktopplevelser. Healing Experiences and the Lived Body. Turning Point Experiences. Tidsskrift for Sjelesorg 2: 133-54.

Nygaard, Marianne Rordiguez, Anne Austad, Elisabeth Mæland, and Tormod Kleiven. Religious Healing Experiences and Earned Security. Pastoral Psycology 1-21. [CrossRef]

Pattison, Stephen. 2007. Healing: A Flight from Definition. In The Challenge of Practical Theology: Selected Essays. London: Jessica Kingsley, pp. 125-32.

Porterfield, Amanda. 2005. Healing in the History of Christianity. Oxford: Oxford University Press.

Rambo, Lewis R., and Charles E. Farhadian. 2014. The Oxford Handbook of Religious Conversion. Oxford: Oxford University Press.

Russo-Netzer, Pninit. 2017. "Sometimes I Don't Even Know Where I Am Going": What Supports Individualized Personal Spiritual Change? Psychology of Religion and Spirituality 9: 82-94. [CrossRef]

Smith, Jonathan A., Paul Flowers, and Michael Larkin. 2009. Interpretative Phenomenological Analysis, Theory, Method and Research. London: Sage Publications.

Statistics Norway. 2019. Available online: https://www.ssb.no/en/kultur-og-fritid/statistikker/kirke_kostra/aar (accessed on 24 August 2020).

Taves, Ann. 2020. Mystical and Other Alterations in Sense of Self: An Expanded Framework for Studying Nonordinary Experiences. Perspectives on Psychological Science 15: 669-90. [CrossRef]

Uotinen, Joanna. 2011. Senses, Bodily Knowledge, and Autoethnography: Unbeknown Knowledge From an ICU Experience. Qualitative Health Research 21: 1307-15. [CrossRef]

Watts, Fraser. 2011. Spiritual Heling: Scientific and Religious Perspectives. Cambridge: Cambridge University Press.

White, Rhea A., and Suzanne V. Brown. 2000. Dictionary of EHE-Related Terms: An Experiencer's Guide. Available online: https://www.ehe.org/display/ehe-page5ced.html?ID=4 (accessed on 24 August 2020).

Wulff, David M. 2000. Mystical Experience. In Varieties of Anomalous Experience: Examining the Scientific Evidence. Edited by Etzel Cardeña, Steven Jay Lynn and Stanlay Krippner. Washington, DC: American Psychological Association, pp. 397-440.

Zinnbauer, Brian J., and Kenneth I. Pargament. 2005. Religiousness and Spirituality. In Handbook of the Psychology of Religion and Spirituality. Edited by Raymond F. Paloutzian and Crystal L. Park. New York: Guilford Press, pp. 21-42.

Publisher's Note: MDPI stays neutral with regard to jurisdictional claims in published maps and institutional affiliations.

(C) 2020 by the authors. Licensee MDPI, Basel, Switzerland. This article is an open access article distributed under the terms and conditions of the Creative Commons Attribution (CC BY) license (http://creativecommons.org/licenses/by/4.0/). 